\title{
IMPLEMENTASI PERUBAHAN KEBIJAKAN BATAS USIA PERKAWINAN
}

\author{
B.Rini Heryanti \\ Fakultas Hukum, Universitas Semarang, Semarang \\ rini.heryanti@usm.ac.id
}

\begin{abstract}
Abstrak
Penelitian ini bertujuan untuk mengkaji implementasi dari Undang-Undang Nomor 16 Tahun 2019 tentang Perubahan Undang-Undang Nomor 1 Tahun 1974. Penetapan batas atas usia perkawinan untuk laki- laki (Pasal 7 ayat 1) dinilai sudah tidak sesuai lagi, dan berdampak pada tingginya angka kematian ibu dan anak, adanya diskriminasi dalam konteks pelaksanaan hak untuk membentuk keluarga sebagaimana dijamin dalam Pasal 28B ayat (1) UUD 1945, terjadinya disharmonisasi dengan Undang-Undang Nomor 35 Tahun 2014 tentang Perubahan UU Nomor 23 Tahun 2002 tentang Perlindungan Anak. Perubahan batas usia perkawinan yang baru yaitu menjadi 19 (sembilan belas ) tahun baik untuk perempuan maupun laki-laki. Berkaitan dengan hal tersebut, maka permasalahan-permasalahan yang ada di masyarakat perlu untuk dikaji lebih mendalam, dalam hal ini mengenai implementasi batas usia perkawinan dalam Undang-Undang Nomor 16 Tahun 2019. Metode penelitian menggunakan metode pendekatan yuridis sosiologis. Hasil dari penelitian ini menjelaskan bahwa implementasi UU No 16 tahun 2019 sudah dilaksanakan baik di KUA maupun Dukcapil namun belum optimal, hal ini nampak adanya beberapa permohonan kasus perkawinan yang dilakukan dibawah batas usia perkawinan, banyaknya dispensasi yang dikeluarkan oleh pengadilan agama dan negeri sebagai sarana untuk melanggengkan perkawinan dibawah batas usia.
\end{abstract}

Kata kunci : Implementasi; Batas Usia; Perkawinan. 


\title{
THE IMPLEMENTATION OF POLICY CHANGED RELATED TO THE AGE LIMIT MARRIAGE
}

\begin{abstract}
The purpose of this research is to review the implementation of act No. 16 of 2019 concerning Amendment to act No. 1 of 1974. The marriage age limit for men (Article 7 paragraph 1) is considered no longer approp riate, and has an impact on the high mortality rate of mothers and children, discrimination in the context of the implementation of the right to form a family as guaranteed in Article $28 B$ paragraph (1) of the 1945 Constitution, the occurrence of disharmony with act No. 35 of 2014 on amendments to act No. 23 of 2002 on Child Protection. The new marriage age limit changes to 19 (nineteen) years for both women and men. Related to this, the problems in the community need to be studied more thoroughly, in this case regarding the implementation of the marriage age limit in act No. 16 of 2019. Research methods used in research with sociological juridical approach methods. The results of research showed that the implementation of act No. 16 of 2019 has been implemented both in KUA and Dukcapil but not optimal, it appears that there are several applications for marriage cases conducted under the marriage age limit, the number of dispensations issued by the Religious and District Courts as a means to perpetuate marriage below the age limit.
\end{abstract}

Keywords: Implementation; Age Limit; Marriage. 


\section{PENDAHULUAN}

\section{A.Latar Belakang}

Kodrat manusia sejak dilahirkan ke dunia adalah sebagai makhluk sosial yang mempunyai sifat hidup bersama-sama dengan sesama manusia. Dapat diartikan bahwa secara makro hidup bersama diawali dengan adanya perkawinan untuk membentuk sebuah keluarga. Terbentuknya sebuah keluarga itu sendiri pada awalnya dibentuk oleh sepasang manusia laki-laki dan perempuan. Hidup bersama antara laki-laki dan perempuan yang telah memenuhi persyaratan perkawinan tersebut disebut sebagai pernikahan. ${ }^{1}$

Ketentuan batas usia perkawinan dalam Undang-Undang Nomor 1 Tahun 1974 ditentukan dalam Pasal 7 ayat (2), yang menyebutkan "batasan usia perkawinan yakni 16 tahun untuk perempuan dan 19 tahun untuk laki-laki”. Hal ini telah berjalan kurang lebih 35 (tiga puluh lima) tahun dan banyak permasalahan sosial, ekonomi yang timbul dalam prakteknya baik di masyarakat perkotaan terlebih-lebih pada masyarakat tradisional/masyarakat adat. Salah satu dampak yang ada yakni belum siapnya alat reproduksi anak perempuan sehingga berkontribusi pada tingginya angka kematian ibu yang melahirkan serta anaknya, bayi-bayi yang malnutrisi dan anak stunting. Sebagai contoh salah satu daerah di Indonesia yang masih tinggi angka kematian ibu dan anak yakni daerah Jawa Tengah yang mencapai 4.481 (empat ribu empat ratus delapan puluh satu) kasus (data BPS Propinsi Jawa Tengah 2018).

Perkawinan anak juga mencedarai semangat perlindungan atas hak asasi manusia yang dilakukan oleh pemerintah. Beberapa undang-undang yang telah dikeluarkan oleh pemerintah dalam usahanya memberikan jaminan perlindungan anak yakni Undang-Undang Nomor 23 Tahun 2002 tentang Perlindungan anak yang diperbaharui dengan Undang-Undang Nomor 35 Tahun

1 Akhmad Shodikin, "Pandangan Hukum Islam Dan Hukum Nasional Tentang Batas Usia Perkawinan”, Jurnal Mahkamah 9 (1), 2015, hal 115. DOI : 10.24235/mahkamah.v9i1.4 
2014 tentang Perubahan Undang-Undang Nomor 23 Tahun 2002 tentang Perlindungan Anak, definisi anak sebagai "seseorang yang belum berusia 18 tahun" dengan demikian ketentuan seseorang dianggap dewasa bila sudah berusia 18 tahun. Hal ini terdapat juga dalam Undang-Undang Nomor 11 Tahun 2012 tentang Sistem Peradilan Pidana Anak.

Adanya permohonan dispensasi melalui pengadilan (Pasal 7 ayat (2) UU Perkawinan) khususnya bagi anak perempuan yang belum berusia 16 tahun, merupakan upaya dari orang tua untuk menyelamatkan status anak dan aib keluarga justru melanggengkan praktik-praktik perkawinan dibawah batasan usia perkawinan. Pengaturan tentang batas minimal usia perkawinan yang diatur dalam pasal 7 ayat (1) dianggap bertentangan dengan Undang-Undang Dasar Negara Republik Indonesia Tahun 1945 dan perlindungan hak asasi manusia, khususnya hak anak. ${ }^{2}$

Menyikapi permasalahan yang timbul karena dampak batas usia perkawinan, masyarakat sipil mendesak pemerintah untuk merevisi isi dari Undang-Undang Perkawinan khususnya Pasal 7 Undang-Undang Perkawinan. Mahkamah Konstitusi pada akhirnya mengeluarkan putusan untuk mendukung perubahan Undang-Undang Perkawinan dengan Putusan Mahkamah Konstitusi Nomor 22/PUU-XV/2017 tentang uji materil Undang-Undang Nomor 1 Tahun 1974 tentang Perkawinan, khususnya terkait dengan Pasal 7 ayat 1 , dapat segera dilaksanakan.

Argumentasi atau salah satu pertimbangan Mahkamah Konstitusi dalam putusan tersebut yaitu "Namun tatkala pembedaan perlakuan antara pria dan wanita itu berdampak pada atau menghalangi pemenuhan hak-hak dasar atau hak-hak konstitusional warga negara, baik yang termasuk ke dalam kelompok hak-hak sipil dan politik maupun hak-hak ekonomi, pendidikan, sosial, dan

${ }^{2}$ Koalisi Perempuan Indonesia, "Perkawinan Anak Penundaan Sidang JR di MK dan Gagalnya Capaian Tujuan Pembangunan Berkelanjutan”, 18 Desember 2017. 
kebudayaan, yang seharusnya tidak boleh dibedakan semata-mata berdasarkan alasan jenis kelamin, maka pembedaan demikian jelas merupakan diskriminasi".

Batas usia 19 (sembilan belas) tahun dinilai dewasa baik secara psikologis, jasmani dan rohani. Ketika kedua mempelai dalam melangsungkan perkawinan sudah dalam batas usia yang dewasa akan dapat mengurangi permasalahan yang timbul pada saat perkawinan. Sehingga angka perceraian dapat turuin seiring dengan semakin menurunnya angka perkawinan di bawah umur. Perubahan Undang-Undang Perkawinan menjadi Undang-Undang Nomor 16 Tahun 2019 ini, diharapkan membawa perubahan yangsangat besar dalam pelaksanaan perkawinan terutama pada batasan usia perkawinan dan meminimalisasi dampak negatif sosial, ekonomi seperti yang terjadi pada Undang-Undang Perkawinan yang lama.

Beberapa penelitian sebelumnya telah ada yang meneliti tentang batasan usia perkawinan. Penelitian oleh Supri Yadin Hasibuan (2019) lebih fokus mengkaji bagaimana pembaharuan hukum tentang pengaturan tentang batas usia minimal perkawinan. Permasalahan yang diangkat dalam penelitian tersebut adalah faktor-faktor apa yang menjadi alasan terjadinya perkawinan dibawah umur dan bagaimana dampak dari adanya perkawinan di bawah umur. Kesimpulan dari penelitian tersebut yaitu bahwa belum ada norma yang mengatur tentang perkawinan anak dibawah umur. Pengaturan hanya mengatur tentang batasan minimal usia perkawinan adalah 19 tahun. Tetapi hal tersebut tidak berlaku apabila ada dispensasi kawin. ${ }^{3}$

Penelitian oleh Nahdiyanti dkk (2021) yang mengangkat judul penelitian 'Implementasi Perubahan Kebijakan Batas Usia Perkawinan Terhadap Perkawinan Di Bawah Umur”. Penelitian ini lebih fokus mengkaji bagaimana implementasi perubahan pengaturan batas usia minimal perkawinan pasca diberlakukannya UU No 16 Tahun 2019. Penelitian tersebut juga menganalisi

3 Supri Yadin Hasibuan, "Pembaharuan Hukum Perkawinan Tentang Batas Minimal Usia Pernikahan dan Konsekuensinya", Teraju: Jurnal Syariah dan Hukum 1 (2) 2019, hal 79-87.

DOI: $\underline{\text { https://doi.org/10.35961/teraju.v1i02.88 }}$ 
bagaimana dampak yang terjadi di masyarakat akibat adanya perubahan norma hukum yang mengatur batasan minimal usia perkawinan. Lokasi penelitian dilaksanakan di Provinsi Sulawesi Selatan. Hasil dari penelitian tersebut menjelaskan bahwa perubahan pengaturan tentang batasan usia minimal perkawinan memberikan dampak yaitu meningkatnya usia perkawinan anak di tahun 2020 ini yang mencapai 132\% dibandingkan dengan data tahun sebelumnya. Kesadaran masyarakat terutama di pedesaan yang masih minim tentang arti pentingnya menikah di usia yang telah menginjak dewasa menjadi salah satu penyebab tingginya perkawinan anak di bawah umur. ${ }^{4}$

Sedangkan penelitian oleh Yusuf (2020) yang mengangkat judul "Dinamika Batasan Usia Perkawinan Di Indonesia : Kajian Psikologi Dan Hukum Islam". Penelitian ini sedikit berbeda dengan penelitian sebelumnya, penelitian ini lebih khusus meneliti batasan usia perkawinan dilihat dari sudut psikologi dan hukum Islam. Dilihat dari sudut psikologis, perkawinan dibawah umur sangat rentan timbul masalah hukum, masalah biologis, psikologis, masalah ekonomi dan sosial serta rentan akan adanya perilaku seks yang menyimpang. Sedangkan dalam hukum Islam itu sendiri tidak mengenal batas usia bagi calon mempelai perkawinan. Hal ini akan menimbulkan perbedaan pendapat terkait dengan kejelasan batas usia dewasa baik bagi calon mempelai laki-laki maupun batas usia dewasa bagi calon mempelai perempuan. ${ }^{5}$

Perbedaan penelitian batasan minimal usia perkawinan dengan penelitian tentang batas an minimal usia perkawinan sebelumnya adalah penelitian ini lebih fokus meneliti tentang implementasi batasan minimal usia perkawinan menurut UU No 16 tahun 2019. Perbedaan penelitian selanjutnya antara penelitian oni denganpenelitian sebelumnya adalah lokasi penelitian ini terletak di Kota

\footnotetext{
${ }^{4}$ Nahdiyanti, Ahyuni Yunus, Nurul Qamar, “Implementasi Perubahan Kebijakan Batas Usia Perkawinan Terhadap Perkawinan Di Bawah Umur", Journal of Lex Generalis 2 (1), 2021, hal 150-167.

DOI: $\frac{\text { https://doi.org/10.52103/ilg.v2i1.313 }}{\text { Yusuf, }}$

5 Yusuf, "Dinamika Batasan Usia Perkawinan Di Indonesia : Kajian Psikologi Dan Hukum Islam" Journal of Islamic Law 2 (1) 2020, hal 200-217. DOI: $\underline{\text { https://doi.org/10.24260/jil.v1i2.59 }}$
} 
Semarang. Tujuan dari penelitian ini untuk menganalisis bagaimanakah implementasi batas usia perkawinan dalam Undang-Undang Nomor 16 Tahun 2019 di Kota Semarang.

\section{B.PERMASALAHAN.}

Bagaimanakah implementasi batas usia perkawinan dalam Undang-Undang Nomor 16 Tahun 2019 di Kota Semarang?

\section{Metode Penelitian.}

1. Metode pendekatan.

Metode penelitian yang digunakan yaitu metode pendekatan yuridis sosiologis yang didasarkan atas kajian terhadap bekerjanya hukum di dalam masyarakat. Bekerjanya hukum dalam masyarakat dapat dikaji dari tingkat efektifitas hukum ${ }^{6}$.

Dalam penelitian ini dilakukan dengan mengkaji bekerjanya hukum yang dikonsepkan sebagai kaidah perundang-undangan, dalam hal ini adalah Undang-Undang Nomor 16 Tahun 2019 tentang Perubahan Undang-Undang Nomor 1 Tahun 1974 khususnya penerapan Pasal 7 ayat (1) mengenai batas usia perkawinan sebagai salah satu syarat dalam pencatatan perkawinan.

2. Spesifikasi Penelitian

Spesifikasi penelitian yang digunakan dalam penelitian ini adalah deskriptif analitis, yaitu "memaparkan dan menjelaskan data yang ditemukan dalam pene litian secara sis tematis dengan pendekatan kualitatif, dengan tujuan untuk memberi gambaran secara menyeluruh, dan mendalam tentang suatu keadaan atau gejala yang diteliti. Menggambarkan secara tepat sifat-sifat sesuatu individu, keadaan, gejala, atau kelompok tertentu atau untuk menentukan ada tidaknya hubungan antara gejala satu dengan gejala lain dalam masyarakat".

\section{Lokasi Penelitian dan Metode Sampel}

${ }^{6}$ Salim HS dan Erlis Septiana Nurbani, "Penerapan Teori Hukum Pada Penelitian Tesis dan Disertasi", PT Grafindo Persada, 2013 Jakarta. 
Penelitian ini dilakukan di Kantor Urusan Agama (KUA), Dinas Kependudukan dan Pencatatan Sipil (DUKCAPIL) di Kota Semarang. Berdasarkan pemilihan lokasi penelitian, dipilih sampel dalam penelitian dengan metode penentuan purposive sampling yaitu "pemilihan sampel didasarkan atas dasar pertimbangan tertentu, dengan tujuan untuk memperoleh satuan sampling yang memiliki karakteristik atau kriteria yang dikehendaki”. Sampel diambil di KUA Semarang Timur, KUA Semarang Tengah dan DUKCAPIL Kota Semarang, pemilihan sampel implementasi batas usia perkawinan dalam Undang-Undang Nomor 16 Tahun 2019 di Kota Semarang dilakukan di kedua kecamatan tersebut yang dianggap dapat mewakili populasi.

\section{Jenis Dan Teknik Pengumpulan Data}

Bahan atau data yang dibutuhka dalam penelitian ini diperoleh melalui wawancara, kuesioner dan studi pustaka. kemudian diolah dan selanjutnya dianalisis untuk mencari jawaban dari permasalahan penelitian yang diajukan. Sesuai dengan metode penelitian dengan metode pendekatan yuridis sosiologis, maka data-data yang hendak dikumpulkan adalah data primer dan data sekunder.

Data sekunder diperoleh dengan mempelajari bahan-bahan pustaka yang berupa perundang-undangan dan literatur lainnya yang berkaitan dengan permasalahan yang dibahas.

Penelitian ini menggunakan bahan hukum baik itu bahan hukum primer, bahan hukum sekunder dan bahan non hukum yang terdiri dari :

1) Bahan Hukum Primer yaitu bahan hukum yang mengikat yakni :

a. Undang-Undang Dasar 1945

b. Kitab Undang-Undang Hukum Perdata

c. Undang-Undang Nomor 1 tahun 1974 tentang Perkawinan

d. Undang-Undang Nomor 16 tahun 2019 tentang Perubahan atas Undang-Undang Nomor 1 Tahun 1974 tentang Perkawinan

e. Undang-Undang Nomor 23 Tahun 2002 tentang Perlindungan Anak, 
2) Bahan Hukum Sekunder, yang memberikan penjelasan mengenai Bahan Hukum Primer. Dalam penelitian ini bahan hukum yang digunakan :

a. buku-buku tentang hukum perkawinan

b. hasil penelitian terdahulu yang berkaitan dengan batas usia perkawinan

c. pandangan para ahli.

3) Bahan Non Hukum

Bahan Non Hukum ini sifatnya untuk menunjang Bahan Hukum Primer dan Bahan hukum sekunder yang mencakup bahan-bahan di luar bidang hukum, seperti ensiklopedi, sosiologi hukum.

5. Metode Analisis Data

Analisis data dalam penelitian ini dilakukan dengan analisis kualitatif, dengan cara melakukan langkah-langkah pengumpulan data, kemudian data yang telah terkumpul dalam penelitian ini diidentifikasi, dikategorikan dan dianalisis secara kualitatif untuk mengungkapkan kebenaran dan memahami kebenaran. Dari hasil analisis tersebut kemudian akan ditarik kesimpulan sebagai jawaban atas permasalahan yang ada.

\section{PEMBAHASAN}

\section{Implementasi Batas Usia Perkawinan Dalam Undang-Undang Nomor 16 Tahun 2019 Di Kota Semarang}

Berdasarkan hasil Survei Penduduk Antar Sensus (SUPAS) 2015 jumlah penduduk Indonesia pada 2020 diperkirakan mencapai 269,6 juta jiwa. Dari data tersebut terdiri dari 135,34 adalah laki-laki dan perempuan mencapai 134,27 jiwa. Artinya jumlah penduduk Indonesia pada tahun 2020 akan banyak berjenis kelamin laki-laki. Sedangka penyebaran jumlah penduduk sebanyak $46 \%$ tersebar hanya di tiga provinsi di pulau Jawa yaitu Provinsi Jawa Tengah 4,55 juta jiwa, Provinsi Jawa Barat sebanyak 49 juta jiwa dan Provinsi Jawa Timur sebanyak 39,74 juta jiwa.

Penyebaran penduduk di provinsi Jawa Tengah sendiri khusus di Kota Semarang jumlah penduduknya mencapai 1.814.110 jiwa. Dalam beberapa 
tahun terakhir ini kota Semarang diminati para pendatang untuk datang atau menetap di kota Semarang, hal ini dikarenakan perkembangan Kota Semarang yang pesat baik dalam kegiatan ekonomimnya, pariwisata dan lan-lain. terutama adanya fasilitas-fasilitas yang diberikan oleh pemerintah kota, menjadikan Kota Semarang sebagai kota harapan bagi pencari kerja dengan upah pekerja yang lebih tinggi apabila dibandingkan dengan kota-kota lainnya di Jawa Tengah. Proses urbanisasi yang sedemikian cepat yang menyebabkan Kota Semarang menjadi terpadat penduduknya di Jawa Tengah, yang pada tahun-tahun lalu Kabupaten Brebes yang menempati urutan pertama kepadatan penduduknya di Jawa Tengah. Sejak tahun 2019 Kota Semarang menempati peringkat pertama kepadatan penduduknya di Jawa Tengah. Jumlah penduduk yang besar ini akan menjadi nilai tambah dalam menggerakkan roda perekonomian. Terlebih lagi, sebagian besar tulang punggung perekonomian di Kota Semarang masih ditopang sektor ind ustri dan kemudian berikutnya adalah perdagangan.

Tentunya dengan kondisi penduduk yang padat ini, Pemerintah Kota Semarang harus bekerja lebih keras dalam menjaga kondufsivitas lingkungannya, karena berbagai masalah ekonomi dan sosial pasti akan muncul, seperti pada penduduk usia produktif yang paling tinggi di Kota Semarang mengharuskan Pemerintah Kota Semarang lebih bersinergi dengan dunia industri untuk menekan angka penganguran, dan dari segi sosial salah satunya adalah dalam hal perkawinan, khususnya pada batasan usia perkawinan yang mempunyai berbagai macam dampak sosial yang timbul.

Pasal 1 Undang-Undang Nomor 16 tahun 2019 tentang Perubahan Undang-Undang Nomor 1 tahun 1974 tentang Perkawinan (untuk selanjutnya dipakai dengan istilah Undang-Undang Perkawinan) "Perkawinan ialah ikatan lahir dan batin antara seorang pria dengan seorang wanita sebagai suami-isteri dengan tujuan membentuk keluarga (rumah tangga) yang bahagia dan kekal berdasarkan Ketuhanan Yang Maha Esa”. Dari pengertian perkawinan pada Pasal 1 Undang-Undang Perkawinan dapat diartikan "bahwa ada 5 (lima) unsur yang penting yaitu, ikatan lahir batin, hubungan 
seorang pria dan seorang wanita, sebagai suami isteri, tujuan perkawinan, berdasarkan Ketuhanan Yang Maha Esa”.

Undang-undang Perkawinan ini menganut prinsip, bahwa pasangan suami istri harus telah matang jiwa dan raga untuk melaksanakan perkawinan. Dengan siapnya jiwa dan raga mereka dalam perkawinan diharapkan perkawinan tersebut jauh dari perceraian karena dapat berjalan dengan langgeng sehingga akan menghasilkan keturunan yang baik dan sehat. Maksud dari pemerintah menerapkan kebijakan ini adalah baik pasangan suami dan istri sama-sama telah berusia minimal 19 tahun agar kedua pasangan tersebut benar-benar siap secara mental, lahir dan batin kertika memasuki perkawinan. ${ }^{7}$

Pendewasaan Usia Perkawinan (PUP) adalah "upaya untuk meningkatkan usia pada perkawinan pertama, sehingga pada saat perkawinan mencapai PUP bukan sekedar menunda perkawinan sampai usia tertentu saja, akan tetapi juga mengusahakan agar kehamilan pertama terjadi pada usia yang cukup dewasa". Hal ini berarti jika seseorang melaksanakan perkawinan dibawah umur, maka langkah selanjutna adalah menunda kelahiran atau kehamilan pertama sampai dengan minimal usia dewasa. Penundaan usia kehamilan dan kehamilan anak pertama ini dalam istilah komunikasi, informasi, dan edukasi (KIE) disebut sebagai anjuran untuk mengubah bulan madu menjadi tahun madu". 8

Berdasarkan ke lima unsur yang ada dalam perkawinan, unsur yang ke tiga adalah tujuan dariperkawinan yakni membentuk keluarga yang terd iri dari ayah, ibu dan anak. Anak sebagai generasi penerus keluarga/ keturunan tentulah sangat diharapkan oleh setiap keluarga dan berharap mendapatkan

7 Slamet Arofik, Alvian Riski Yustomi "Analisis Ushul Dan Kaidah Fikih Terhadap Implementasi Dispensasi Perkawinan Di Bawah Umur Di Kantor Urusan Agama (KUA)Kecamatan Perak Kabupaten Jombang”, Jurnal Usratuna 4 (1), 2020, hal 117. DOI: $\frac{\text { https://doi.org/10.29062/usratuna.v4i01.260 }}{8}$

8 Holilur Rohman, "Batas Usia Ideal Pernikahan Perspektif Maqasid Shariah", Journal of Islamic Studies and Humanities 1 (1), 2016, hal 77. 10.21580/jish.11.1374 
penerus generasi yang dapat dibanggakan oleh keluarga tersebut. Agar bisa memperoleh generasi penerus keluarga yang demikian itu, maka kematangan dan kesiapan calon suami dan seorang isteri diutamakan. Bagi seorang perempuan yang akan menikah maka syarat umur dewasa menjadi hal yang pkok. Kedewasaan ini berkaitan dengan kematangan emosional, mental, psikologis dan alat reproduksi perempuan. Oleh sebab itu menaikkan batasan usia perkawinan oleh pemerintah menjadi keniscayaan dalam Undang-Undang Perkawinan.

Mengenai batas usia anak, instrumen hukum yang mengatur usia anak di Indonesia berbeda-beda apabila ditinjau dari beberapa peraturan perundangan-undangan yang ada antara lain, dalam Kitab Undang-Undang Hukum Perdata Buku I dalam Pasal 330 mengatur orang yang belum dewasa adalah "mereka yang belum berumur 21 tahun atau mereka yang belum berumur 21 tahun tetapi telah menikah".

Undang-Undang Nomor 35 Tahun 2014 tentang Perubahan atas Undang-Undang Nomor 23 Tahun 2002 tentang Perlindungan Anak sebagai instrumen HAM, menyebutkan batasan usia anak dalam Pasal 1 ayat 1 sebagai berikut : "Anak adalah seseorang yang belum berusia 18 (delapan belas) tahun, termasuk anak yang masih dalam kandungan". Namun untuk batasan usia perkawinan baik Undang-Undang Nomor 35 Tahun 2014 maupun Undang-Undang Nomor 23 Tahun 2002 tidak menyebutkan secara eksplisit tentang batas usia minimum menikah, hanya dalam asas dan tujuan dari Undang-Undang Nomor 23 Tahun 2002 pada pasal 2 disebutkan, "penyelenggaraan perlindungan anak berasaskan Pancasila dan berlandaskan Undang-Undang Dasar Negara Republik Indonesia Tahun 1945 serta prinsip-prinsip dasar Konvensi Hak-Hak Anak meliputi” :

a. non diskriminasi;

b. kepentingan yang terbaik bagi anak;

c. hak untuk hidup, kelangsungan hidup, dan perkembangan; dan

d. penghargaan terhadap pendapat anak. 
Adanya pembatasan usia minimal perkawinan adalah sebagai bentuk perlindungan hukum terhadap anak. Kesehatan, kesejahteraan dan masa depan anak-anak harus terjaga, hal ini tidak akan terjadi jika perkawinan anak di bawah umur masih banyak terjadi. Mengingat perkawinan dini rentan akan terjadinya kekerasan rumah tangga, kekerasan seksual maupun tingginya perceraian. ${ }^{9}$

Organisasi Kesehatan Dunia (WHO) "memberikan kategori umur yang baru, adanya kategori umur baru yang dikeluarkan WHO membuat pihak yang berwenang mempertimbangkan kembali mengenai pengelompokkan pelayanan terhadap masyarakat. Mulai dari penyusunan kebijakan, program maupun kegiatan dalam upaya meningkatkan kesejahteraan masyarakat perlu ditinjau kembali. Kategori umur WHO tersebut cukup berbeda dengan kategori umur sebelumnya maupun kategori umur dari Departemen Kesehatan Republik Indonesia.Kategori umur yang lama menurut WHO di Tabel 1 sebagai berikut":

Tabel 1

\begin{tabular}{|l|l|}
\hline Kategori & Umur dalam tahun \\
\hline Masa balita & $0-5$ \\
\hline Masa kanak - kanak & $5-11$ \\
\hline Masa remaja awal & $12-16$ \\
\hline Masa remaja akhir & $17-35$ \\
\hline Masa dewasa awal & $36-45$ \\
\hline Masa usia pertengahan & $45-50$ \\
\hline Lanjut Usia & $60-74$ \\
\hline Lanjut usia tua & $75-90$ \\
\hline Usia sangat tua & $>90$ \\
\hline
\end{tabular}

9 Elkhairati, "Pembatasan Usia Perkawinan (Tinjauan Undang-undang dan Maqashidasy-Syari'ah) ', Jurnal Al Istinbath 3(1), 2018, hal 87-106.

DOI : $\underline{\text { 10.29240/jhi.v } 3 \text { i1 } 1.403}$ 
Dampak pembaharuan kategori umur menurut WHO tersebut cukup mengejutkan, mengingat batas usia pemuda 65 (enam puluh lima) tahun. Ini berarti usia 60 tahun tidak lagi dikelompokkan pada usia tua seperti kategori usia yang lama oleh WHO. Usia 17 ( tujuh belas) tahun masih dianggap sebagai anak-anak. Hal ini berbeda dengan pembagian kelompok umur menurut Depkes dimana sebelumnya usia usia 17 (tujuh belas ) tahun sudah masuk kelompok remaja akhir. Hal ini tentu berdampak pada sudut pandang masyarakat terhadap usia yang dianggap dewasa atau tua. Selain itu pelayanan maupun kesehatan untuk masyarakat juga perlu ditinjau kembali. Kebijakan yang dahulu hanya ditujukan khusus untuk remaja saja, saat ini juga harus mempertimbangkan agar dapat dilaksanakan untuk orang berusia 65 (enam puluh lima) tahun ke bawah.

Pertimbangan pembagian usia ini disesuaikan dengan kemampuan orang dalam beraktivitas. Kelompok usia tua ini disesuaikan dengan kemampuan orang dalam beraktvitas. Kelompok usia tua atau manula ditujukan bagi usia 80 (delapan puluh) ke atas dengan kemampuan orang dalam pertimbangan pembagian usia ini disesuaikan dengan kemampuan orang dalam beraktivitas. Kelompok usia tua atau manula ditujukan bagi usia 80 (delapan puluh) tahun ke atas, mengingat terbatas nya aktivitas yang masih bisa mereka lakukan. Untuk penggolongan usia di bawah 65 (enam puluh lima) tahun masih dianggap usia muda atau dewasa karena kelompok umur tersebut dianggap masih dapat melakukan aktifitas dan kegiatan yang sesuai dengan penggolongan usia mereka. Pengelompokan terbaru dari WHO ini bertujuan untuk dapat meningkatkan kesejahteraan dan taraf hidup manusia. Penilaian terhadap kualitas kesehatan dan harapan hidup manusia akan semakin mudah dipantau jika pengelompokan usia tersebut tidak terlalu banyak. Dengan semakin sedikit dan terbatasnya pengelompokkan usia hanya dalam 5 kelompok akan menyebabkan semakin sedikitnya variabel yang dipergunakan dalam perhitungan untuk kepentingan kualitas hidup dan kesehatan mereka sendiri. 
Menurut Departemen Kesehatan R.I, "anak merupakan aset masa depan bangsa yang harus dijaga dan diperhatikan perkembangannya. Karena mereka merupakan penerus yang akan menentukan masa depan bangsa dan negara. Sebagai negara hukum perlindungan terhadap anak sejak masih di dalam kandungan memang merupakan hal yang penting, maka diperlukan batasan-batasan umur anak yang dimasukkan dalam kategori-kategori umur sehingga dalam memberikan pendidikan, perhatian, maupun hal yang lain dapat lebih tepat dalam penerapannya". Adapun kategori-kategori umur yang diberikan oleh Depkes sebagai berikut :

1. Masa balita : $0-5$ tahun

2. Masa kanak-kanak : 5-11 tahun.

3. Masa remaja awal : $12-16$ tahun

4. Masa remaja akhir : $17-25$ tahun

5. Masa dewasa awal : $26-35$ tahun

6. Masa dewasa akhir : $36-45$ tahun.

7. Masa lansia awal : $46-55$ tahun

8. Masa lansia akhir : $56-65$ tahun

9. Masa manula : $>65$ tahun. $^{10}$

Beberapa peraturan yang mengatur batas usia anak belum ada keseragaman, seharusnya dilakukan keseragaman mengenai usia anak. Hal ini sangat penting dalam hukum perdata agar tidak ada kebingungan dalam masyarakat dan agar ada kepastian hukum.Undang-Undang Perkawinan telah merevisi batas usia perkawinan pada pasal 7, yaitu memberlakukan batasan umur yang sama yakni 19 tahun bagi laki- laki dan perempuan. Pada perubahan ini terdapat kemajuan dalam gender karena sudah tidak ada dikriminasi lagi. Namun masih perlu dicermatidalam pelaksanaan batasan usia perkawinan.

Berdasarkan data yang ada pada Kantor Urusan Agama (KUA) Semarang Tengah batasan usia perkawinan sebelum adanya Undang-Undang Nomor 16 Tahun 2019, masih terdapat perkawinan

10 “https://muamalatnet/kategori umur menurut WHO”, diakses pada tanggal 23 Januari 2021. 
dibawah umur yang dilakukan, Apabila dicermati untuk keseluruhanjumlah orang yang melakukan pekawinan selama kurun waktu 4 tahun sangat sedikit, hal terjadi karena jumlah penduduk di Semarang Tengah lebih sedikit apabila dibandingkan dengan jumlah penduduk di Semarang Timur yang lebih banyak pendatangnya. Sedangkan Kecamatan Semarang Tengah sendiri merupakan kawasan bisnis dan perdagangan sehingga hanya banyak dihuni oleh penduduk asli.

Berdasarkan data usia perkawinan yang ada di KUA Semarang Tengah, mulai Januari tahun 2017 sampai dengan September tahun 2019 pelaksanaan perkawinan yang tidak memenuhi syarat usia perkawinan untuk laki-laki hanya 1 orang saja dan perempuan 2 orang yang tidak memenuhi syarat perkawinan. Pelaksanaan perkawinan ini dilaksanakan pada saat masih diberlakukannya perundang-undangan yang lama yakni Undang-Undang Nomor 1 tahun 1974. Setelah diundangkannya UndangUndang Nomor 16 tahun 2019 tentang Perubahan Undang-Undang Nomor 1 tahun 1974 tentang Perkawinan, sedangkan mulai bulan Oktober 2019 sampai dengan bulan Nopember 2020 tercatat pelaksanaan perkawinan yang tidak memenuhi usia perkawinan untuk laki-laki 1 orang dan perempuan 1 orang.

Berbeda dengan Kantor Urusan Agama di Semarang Timur, dengan jumlah penduduk yang lebih banyak, maka pencatatan perkawinan pun semakin banyak. Tercatat yang melakukan perkawinan pada bulan Januari 2017 sampai dengan bulan September 2019 pelaksanaan perkawinan yang tidak memenuhi syarat usia perkawinan untuk laki-laki 18 orang dan perempuan sudah memenuhi syarat perkawinan. Pelaksanaan perkawinan ini dilaksanakan pada saat masih diberlakukannya perundang-undangan yang lama yakni Undang-Undang Nomor 1 tahun 1974. Setelah diundangkannya Undang- Undang Nomor 16 tahun 2019 tentang Perubahan Undang-Undang Nomor 1 tahun 1974 tentang Perkawinan, mulai bulan Oktober 2019 sampai dengan bulan Oktober 2020 tercatat pelaksanaan perkawinan yang tidak memenuhi usia perkawinan untuk 
laki-laki 6 orang dan perempuan 6 orang. Begitu juga pelaksanaan pencatatan di Dukcapil Kota Semarang, dan di Pengadilan Agama Semarang masih tercatat adanya perkawinan dibawah umur,

Berdasarkan data yang ada di lapangan, kenyataannya masih ada ketidakpatuhan para calon pengantin untuk memenuhi syarat perkawinan, terutama pada batas usia perkawinan, baik pada saat diberlakukannya Undang-Undang Perkawinan yang lama (Undang-Undang Nomor 1 Tahun1974) maupun Undang-Undang Pekawinan yang baru ( Undang-Undang Nomor 16 Tahun 2016). Perkawinan anak menjadi salah satu masalah darurat yang dihadapi Indonesia saat ini. Data dari Kementerian PPPA tersebut menempatkan Indonesia pada rangking 7 dunia khusus mengenai angka pernikahan anak. ${ }^{11}$

Faktor-faktor penyebab terjadinya perkawinan anak antara lain : "faktor kemiskinan (ekonomi), anak perempuan dipaksa menikah pada usia muda untuk menolong beban ekonomi keluarga, meringankan beban ekonomi keluarga karena anak perempuan yang dinikahkan sudah tidak menjadi tanggungan orang tuanya lagi. Di beberapa negara yang miskin, anak-anak perempuan dijadikan target untuk dijual atau dinikahkan agar orang tua terbebaskan dari beban ekonomi. Alasan lain adalah kepentingan kasta, tribal serta kekuatan ekonomi dan politik agar anak-anak mereka yang dikawinkan dapat memperkuat keturunan dan status sosial mereka". ${ }^{12}$

Dari penelitian oleh Syahruddin Nawi dan Salle (2020) di Pengadilan Agama Makassar menyimpulkan bahwa faktor ekonomi menjadi salah satu faktor penyebab orang tua mengajukan permohonan dispensasi nikah untuk kepentingan anaknya di Pengadilan Agama Makassar. Pemohon dispensasi nikah menyatakan faktor ekonomi dipilih sebagai salah satu faktor yang berpengaruh. $60 \%$ dari pemohon memilih faktor ekonomi dan $25 \%$

11 Lenny Nurhayati Rosalina, "Mengawal Kedaulatan Bangsa”, Kementerian Pemberdayaan Perempuan dan Anak, Jakarta, 2020.

12 Saras wati Rika, "Hukum Perlindungan Anak Di Indonesia”, PT Citra Aditya Bakti, Bandung, 2015, hal 50. 
menyatakan faktor ekonomi bukan kurang berpengaruh dan 5\% menyatakan faktor ekonomi tidak berpengaruh terhadap pengajuan dispensasi nikah. ${ }^{13}$

Praktik semacam ini di Indonesia sangat bertentangan dengan isi dari Pasal 26 ayat (1) butir c Undang-Undang Nomor 35 Tahun 2014 tentang Perlindungan Anak mengamanatkan "salah satu kewajiban dan tanggung jawab orang tua adalah mencegah terjadinya perkawinan pada usia anak". Isi pasal ini diharapkan anak dapat bertumbuh dengan baik sesuai dengan telentanya, bukan dibebani hal- hal persoalan sosial dalam rumah tangga yang seharusnya tidak ditimpakan kepadanya. Dunia anak, adalah dunia belajar, ceria dan bermain.

Perkawinan anak di bawah umur di samping melanggar hak-hak anak seperti anak yang diharuskan berhenti sekolah karena harus menikah, tindakan ini juga dapat menyebabkan timbulnya kemiskinan antar generasi, merusak masa depan anak-anak. Di Indonesia itu sendiri 1 dari 9 anak menikah pada usia dibawah umur. Perkawinan anak dibawah umur tidak hanya merampas masa kecil anak-anak tetapi juga dapat mengancam kesehatan dan masa depan anak-anak itu sendiri. Anak-nak khususnya perempuan masih relatif lemah dan rentan mengalami kekerasan seksual dan kekerasan dalam rumah tangga. ${ }^{14}$ Kekerasan yang timbul dalam rumah tangga tidak hanya meninggalkan akibat fisik seperti luka serius, cacat fisik maupun mental, dan bahkan yang paling ekstrem bisa mengakibatkan kematian. Padahal kekerasan yang dilakukan oleh suami terhadap isteri sudah jelas merupakan tindak pidana sebagaimana diatur dalam Undang-Undang Nomor 23 Tahun 2004 tentang Penghapusan Kekerasan Dalam Rumah Tangga (Imam Subandi, 2019). Perkawinan anak

13 Syahruddin Nawi, Salle Salle, “Analisis Pengaruh Berbagai Variabel Terhadap Permohonan Dispensasi Pernikahan”, Journal of Lex Philosophy 1 (1), 2020, hal 84-98. DOI : $\underline{\text { https://doi.org/10.52103/jlp.v1i1.28 }}$

${ }^{14}$ https://wwwunicef.org/indonesia/id/press-releases unicef-sambut revisi UUPA indonesia, diakses tanggall 23 Januari 2021. 
juga bertentangan dengan Pasal 28 B ayat (2) Undang-Undang Dasar 1945 yang berisi : "Setiap anak berhak atas kelangsungan hidup, tubuh dan berkembang serta berhak atas perlindungan dari kekerasan dan diskriminasi”.

Faktor lain yang menyebabkan adanya perkawinan anak karena rendahnya pendidikan, pemahaman budaya atau agama dan karena hamil terlebih dahulu (kecelakaan atau populer dengan istilah married by accident /MBE,) ini merupakan faktor ke dua yang banyak terjadi setelah faktor ekonomi. Hal ini biasa terjadi di berbagai wilayah di Indonesia termasuk Kota Semarang. Kalau terjadi kasus yang demikian maka mau tidak mau pejabat KUA/Dukcapil akan menolak permohonan perkawinan dan para pihak diminta untuk memohon dispensasi ke Pengadilan Agama Semarang atau Pengadilan Negeri Semarang. Setelah putusan dari pengadilan agama/ negeri turun baru pejabat KUA/Dukcapil mengabulkan permohonan tersebut.

Perkawinan di bawah umur sangat rentan menghadapi terjadinya perceraian, akibat perceraian dini pada kasus pernikahan di bawah umur menempatkan mereka pada posisi yang tidak ideal. Pada saat anak-anak seharusnya merasakan kasih sayang dan mendapatkan perlindungan mereka malah harus menghadapi kasus perceraian yang disebakan perkawinan di bawah umur yang tidak siap. Dalam pasal 3 Undang-Undang Nomor 23 Tahun 2002 tentang Perlindungan Anak menjelaskan bahwa "Perlindungan anak bertujuan untuk menjamin terpenuhinya hak-hak anak agar dapat hidup, tumbuh, berkembang dan berpartisipasi secara optimal sesuai harkat dan martabat kemanusiaan, serta mendapat perlindungan.."15

15 Junaedi Junaedi, Said Sampara, Dachran S Bustham, "Efektivitas Undang-Undang Nomor 1 Tahun 1974 Tentang Perkawinan Dihubungkan Dengan Perkawinan Dibawah Umur: Studi Kecamatan Pajukukang Kabupaten Bantaeng , , Journal of Lex Generalis 1 (1), 2020, hal 119-133,

DOI: https://doi.org/10.52103/ilg.v1i1 
Masih banyaknya permohonan dispensasi perkawinan dari masyarakat ke pengadilan agama, disikapi oleh pengadilan agama dengan mengabulkan permohonan tersebut, hal ini dilatar belakangi untuk menyelamatkan status anak yang dikandung oleh calon pengantin perempuan, walaupun sudah diberlakukannya Undang-Undang Nomor 16 tahun 2019, namun dengan alasan tertentu undang-undang ini diabaikan. Memang dalam penyelesaian masalah ini seperti buah simalakama artinya kalau pengadilan tidak mengabulkan permohonan dispensasi perkawinan, maka akan terjadi perkawinan siri yang tidak didaftarkan. Tentu hal ini akan mempunyai akibat hukum tersendiri karena perkawinan yang dilakukan secara siri tersebut tidak dilakukan secara tercatat di Kantor Urusan Agama setempat. ${ }^{16}$ Pencatatan perkawinan mempunyai unsur yang sangat penting bagi keabsahan dari perkawinan tersebut. Dengan melakukan pencatatan perkawinan maka para pihak yang melakukan perkawinan mendapatkan perlindungan dari negara dalam membina keluarga dan akan mendapatkan kepastian hukum bagi suami, isteri dan anak-anaknya, juga akan hak mewaris. Lain halnya jika perkawinan itu tidak dicatatkan maka akan berimplikasi pada pegakuan hukum, hak mewaris, status sosial, hak atas identitas, hak anak dan lain sebagainya.

Revisi batas usia perkawinan yang dilakukan oleh pemerintah, merupakan hal yang baik untuk menanggulangi dampak perkawinan anak, namun dalam impelentasinya tentu dibutuhkan pemahaman yang baik di masyarakat, masyarakat dapat menerima dan apabila hal ini sudah dijalankan tentu masyarakat akan mentaati peraturan tersebut. Apalagi faktor budaya, adat, yang masih ada di masyarakat desa yang masih mendukung adanya perkawinan anak. Sebagai contoh mengenai pemberlakukan Undang-Undang Perkawinan Nomor 1 Tahun 1974, mengenai batas umur perkawinan yakni untuk pria berumur 19 ( sembilan

16 Cucu Solihah dkk, "Dampak Kebijakan Isbat Nikah Terhadap Perkawinan Siri dan Campurandi Kabupaten Cianjur”, Masalah-Masalah Hukum 48 (4), 2019. 
belas ) tahun dan untuk perempuan 16 (enam belas) tahun (Pasal 7) menurut Afdol dalam penelitiannya "Pelaksanaan Undang-Undang Nomor 1 Tahun 1974 di Bangkalan Madura", diketemukan masih banyaknya masyarakat yang tidak memenuhi syarat umur perkawinan dalam Undang-Undang Perkawinan, bagaimana mungkin masyarakat desa yang menjadi obyek penelitian dapat mengetahui dan melaksanakan pengaturan tentan perkawinan.

Hasil survei yang dilakukan kepada kepala desa itu sendiri hanya mencapai 25,38 \% bagi kepala desa yang secara tepat dapat menjawab batasan usia minimal perkawinan. Sebagian besar kepala desa tersebut masih belum mengetahui batasan usia minimal perkawinan yang sesuai dengan undang-undang. Penelitian tersebut juga menemukan adanya kebiasaan menikahkan anaknya di bawah umur. Data penelitian menyebutkan sekitar 64,62\% perkawinan di bawah umur diketemukan di sebagian besar desa-desa wilayah Kabupaten Bangkalan. ${ }^{17}$

Hasil penelitian yang dilakukan di Bangkalan Madura dan temuan pada penelitian yang lainnya mengisyaratkan bahwa betapa sulitnya memberikan aturan-aturan baru ditengah budaya masyarakat yang sudah tertanam lama, perlu adanya perubahan sikap dan cara pandang masyarakat untuk memulai hal yang baru ditengah kebiasaan, adat yang sudah mengakar. Tentunya harus ada upaya-upaya lain yakni sinergitas dari pemerintah, pejabat yang berwenang, aparat desa dan tokoh adat dan agama untuk menanamkan konsep yang baru ditengah-tengah norma, aturan yang lama sehingga perubahan nilai, aturan yang diinginkan oleh pemerintah dapat diakui dan dilaksanakan oleh masyarakat.

Pendapat Koentjaraningrat, dalam bukunya Esmi Warassih "Pranata Hukum Sebuah Telaah Sosiologis" yang menyatakan:

17 Esmi Warassih, "Pranata Hukum Sebuah Telaah Sosiologi”, Badan Penerbit Universitas Diponegoro, 2011, Semarang, hal 87. 
"Harus disadari bahwa kebudayaan mempunyai kedudukan dan peranan yang sangat penting di dalam kehidupan manusia. Para individu sejak kecil sudah diresapi oleh nilai-nilai budaya yang hidup dalam masyarakat.. Konsepsi-konsepsi yang dimiliki itu sejak lama telah berakar dalam alam jiwa mereka . Itulah sebabnya nilai-nilai budaya yang sudah dimiliki sukar diganti dengan nilai budaya lain dalam waktu singkat". ${ }^{18}$

Demikan juga berlakunya Undang-Undang Nomor 16 Tahun 2019 sebagai Perubahan dari Undang-Undang Nomor 1 Tahun1974 tentang Perkawinan, akan mengalami hal yang serupa khususnya pada masyarakat desa, terutama dalam pelaksanaan di Pasal 7 mengenai batas usia perkawinan.

\section{PENUTUP}

Perubahan batasan umur yang dilakukan oleh pemerintah dengan merevisi Undang-Undang Perkawinan Nomor 1 tahun 1974 menjadi Undang-Undang Nomor 16 tahun 2019 tentang Peubahan Undang-Undang Nomor 1 tahun 1974 merupakan satu langkah lebih maju dalam kesetaraan gender, namun undang-undang ini belum sepenuhnya dijalankan dan dipatuhi masyartakat terutama di Kota Semarang. Implementasi undang-undang perkawinan ini akan lebih banyak kendala penerapannya di masyarakat desa, yang sudah mempunyai budaya, konsep, cara pandang, adat yang sudah lama mengakar $\mathrm{dn}$ hidup dalam lingkungan masyarakatnya. Untuk merubah mindside dari masyarakat desa dan agar masyarakat dapat menerima serta menjalankan apa yang menjadi tujuan dari undang-undang diperlukan suatu langkah konkrit untuk memberdayakan pejabat daerah sampai dengan kepala desa serta tokoh agama dan tokoh masyarakat.

\footnotetext{
18 Ibid, hal 103.
} 


\section{DAFTAR PUSTAKA}

\section{Buku}

Esmi Warassih, "Pranata Hukum Sebuah Telaah Sosiologi", Badan Penerbit Universitas Diponegoro, Semarang, 2011.

Koalisi Perempuan Indonesia, "Perkawinan Anak Penundaan Sidang Judicial Review di MK dan Gagalnya Capaian Tujuan Pembangunan Berkelanjutan", 2017.

Lenny Nurhayati Rosalina, "Mengawal Kedaulatan Bangsa”, Kementerian Pemberdayaan Perempuan dan Anak, Jakarta, 2020.

Pusat Kajian Hukum Gender, "Naskah Akademik Rencana Perubahan Undang-Undang Nomor 1 Tahun 1974 tentang Perkawinan”, Fakultas Hukum Gajah Mada.

Saraswati Rika, "Hukum Perlindungan Anak Di Indonesia”, PT Citra Aditya Bakti, Bandung, 2015.

Salim HS dan Erlis Septiana Nurbani, "Penerapan Teori Hukum Pada Penelitian Tesis dan Disertasi”, PT Grafindo Persada, Jakarta, 2013.

\section{Jurnal}

Akhmad Shodikin, "Pandangan Hukum Islam Dan Hukum Nasional Tentang Batas Usia Perkawinan", Jurnal Mahkamah 9 (1), 2015. DOI : 10.24235/mahkamah.v9i1.4

Cucu Solihah dkk, "Dampak Kebijakan Isbat Nikah Terhadap Perkawinan Siri dan Campuran di Kabupaten Cianjur", Masalah-Masalah Hukum 48 (4), 2019.

Dimas Dwi Arso, "Sistem Perkawinan dan Pewarisan Pada Masyarakat Hukum Adat Rejang Propinsi Bengkulu", Journal of Indonesia Adat Law (JIAL) 2 (1), 2018.

Elkhairati, "Pembatasan Usia Perkawinan (Tinjauan Undang-undang dan Maqashidasy-Syari'ah)", Jurnal Al Istinbath 3(1), 2018. DOI $: \underline{10.29240 / \text { jhi.v3i1.403 }}$

Holilur Rohman, "Batas Usia Ideal Pernikahan Perspektif Maqasid Shariah", Journal of Islamic Studies and Humanities 1 (1), 2016. 10.21580/jish.11.1374

Junaedi Junaedi, Said Sampara, Dachran S Bustham, "Efektivitas Undang-Undang Nomor 1 Tahun 1974 Tentang Perkawinan Dihubungkan Dengan Perkawinan Dibawah Umur: Studi Kecamatan Pajukukang Kabupaten Bantaeng" , Journal of Lex Generalis 1 (1), 2020. DOI: https://doi.org/10.52103/ilg.v1i1

Nahdiyanti, Ahyuni Yunus, Nurul Qamar, "Implementasi Perubahan Kebijakan Batas Usia Perkawinan Terhadap Perkawinan Di Bawah Umur", Journal of LexGeneralis 2 (1), 2021. DOI: https://doi.org/10.52103/jlg.v2i1.313

Rochmadi Usman, “Hukum Perkawinan”, Journal Legislasi Indonesia 14 (3), 2017.

Slamet Arofik, Alvian Riski Yustomi “Analisis Ushul Dan Kaidah Fikih Terhadap Implementasi Dispensasi Perkawinan Di Bawah Umur Di Kantor Urusan Agama (KUA)Kecamatan Perak Kabupaten Jombang ”, Jurnal Usratuna 4 (1), 2020. DOI: https://doi.org/10.29062/usratuna.v4i01.260 
Supri Yadin Hasibuan, "Pembaharuan Hukum Perkawinan Tentang Batas Minimal Usia Pernikahan dan Konsekuensinya", Teraju: Jurnal Syariah dan Hukum 1 (2) 2019.

DOI: https://doi.org/10.35961/teraju.v1 i02.88

Syahruddin Nawi, Salle Salle, "Analisis Pengaruh Berbagai Variabel Terhadap Permohonan Dispensasi Pernikahan", Journal of Lex Philosophy 1 (1), 2020.

DOI : https://doi.org/10.52103/jlp.v1i1.28

TeukuYudi Afrizal, "Dispensasi Perkawinan Dibawah Umur Dalam Perpektif dan Perundang-Undang Bidang Perkawinan di Mahkamah Syar'iyah Lhokseumawe",. Jurnal Hukum Acara Perdata 6 (1), 2019.

Yusuf, "Dinamika Batasan Usia Perkawinan Di Indonesia : Kajian Psikologi Dan Hukum Islam" Journal of Islamic Law 2 (1) 2020. DOI: https://doi.org/10.24260/jil.v1i2.59

\section{Undang-Undang}

Undang-Undang Dasar R.I 1945

Kitab Undang-Undang Hukum Perdata

Undang-Undang Nomor 1 tahun 1974 tentang Perkawinan

Undang-Undang Nomor 35 Tahun 2014 tentang Perubahan atas Undang-Undang Nomor 23 Tahun 2002 tentang Perlindungan Anak.

Undang - Undang Nomor 16 Tahun 2019 tentang tentang Perubahan Undang-Undang Nomor 1 tahun 1974 tentang Perkawinan.

\section{Internet}

"https://muamalatnet/kategori umur menurut WHO".

"https://wwwunicef.org/indonesia/id/press-releases unicef-sambut revisi UUPA indonesia"

"https://databoks.katadata.co.id/datapub lish/2020/01/02/inilah-proyeksi-jumlah-pe nduduk-indonesia-2020" 